\title{
An Overview of Strawberry Production in Mexico ${ }^{1}$
}

\author{
Feng Wu, Zhengfei Guan, J. Jaime Arana-Coronado, and Melvin Garcia-Nazariega ${ }^{2}$
}

\section{Introduction}

Mexico was the second largest strawberry-producing country in the world in 2013, following the United States (FAO 2014). In recent years, rapid increases in acreage and production capacity of the Mexican strawberry industry have created great challenges for the US strawberry industry (Suh et al. 2017). Over a ten-year period (2004-2014), Mexican strawberry exports to the United States increased approximately fourfold, from 93 million pounds in 2004 to 355 million pounds in 2014 (USDC 2015). To put this in perspective, Florida strawberry total production in 2004 and 2014 was 179 and 207 million pounds, respectively. Imports from Mexico were approximately half of total Florida production in 2004, compared to roughly two times greater than Florida production in 2014. Given the tremendous influence of Mexican strawberries in the US market, it is important to have a better understanding of the Mexican strawberry industry, particularly strawberry production in Central Mexico, the major production area in Mexico that has the same production window and directly competes with Florida in the winter strawberry market. This article provides an overview of Mexican strawberry production, with an emphasis on the production in Central Mexico.

\section{Strawberry Production}

Mexican strawberry production is experiencing rapid growth. In 2014, Mexico's strawberry production (fresh and frozen) reached 1,012 million pounds, 2.5 times its

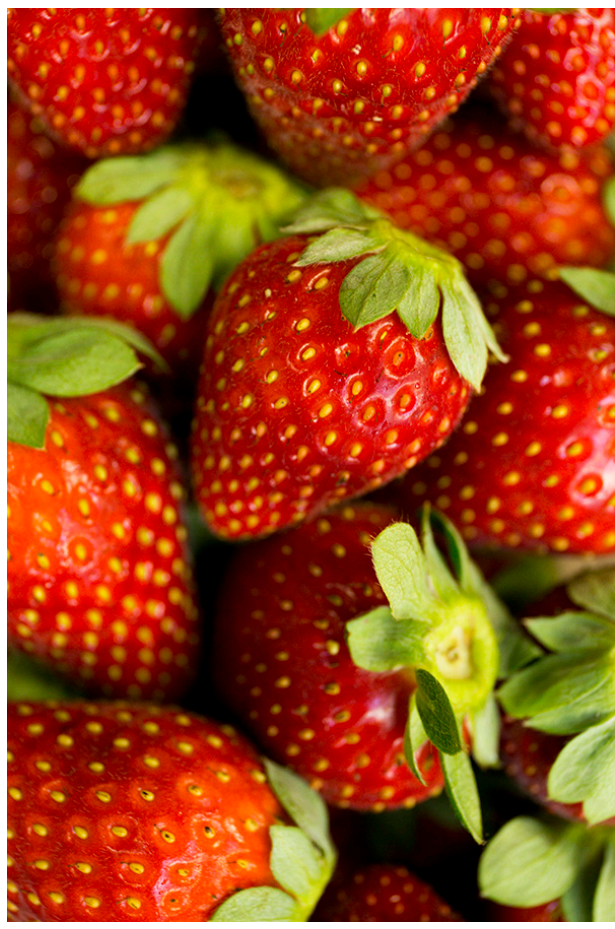

Tyler Jones, UF/IFAS

production in 2004. Mexico has two major production areas: Baja California and Central Mexico (including Michoacán, Guanajuato, Jalisco, and Mexico states). Due to geographic distance, the two areas have different production seasons. Baja California mainly produces in the summer, while Central Mexico produces in the winter. The total planted acreage in Mexico was 17,310 and 24,629 acres in 2011 and 2014, respectively. Strawberry production in

1. This is EDIS document FE1014, a publication of the Food and Resource Economics Department, UF/IFAS Extension. Published December 2017. Visit the EDIS website at http://edis.ifas.ufl.edu.

2. Feng Wu, research assistant scientist, Food and Resource Economics Department; and Zhengfei Guan, assistant professor, Food and Resource Economics Department, UF/IFAS Gulf Coast Research and Education Center, Balm, FL. J. Jaime Arana-Coronado, professor, Postgraduate College, Texcoco, Mexico; and Melvin Garcia-Nazariega, agro-purchasing manager, Frexport SA de CV, Zamora, Mexico. 


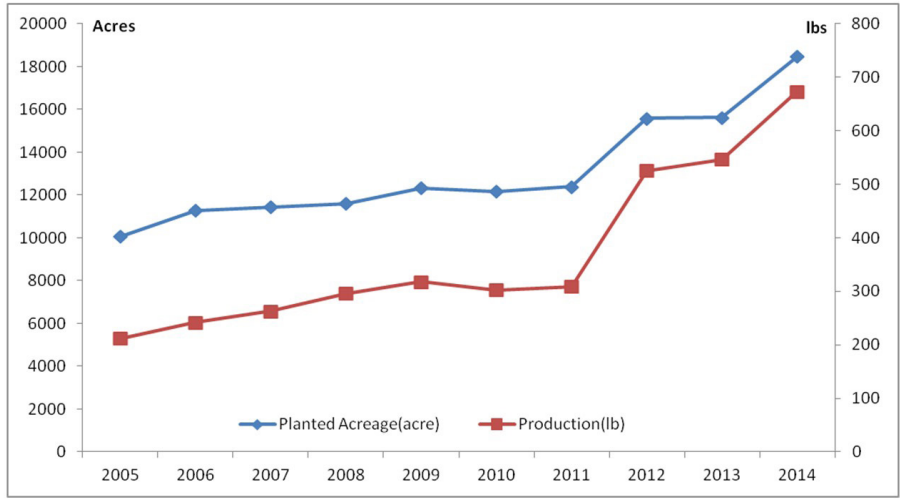

Figure 1. Strawberry planted acreage and production in Central Mexico, 2005-2014 (Source: Agrifood and Fisheries Information Service of Mexico 2016).

Central Mexico, accounting for about $65 \%$ of total Mexican strawberry volume, leads the growth in Mexican strawberry production. Due to the growing US demand for winter strawberries, the acreage in this area has expanded rapidly (Figure 1). Central Mexico's total planted area was 12,387 acres in 2011, and 18,458 acres in 2014, representing an approximately $50 \%$ growth. The increase in acreage, ideal weather, and changes in production technology have led to the high output. Production in Central Mexico reached 673 million pounds in 2014, which is twice as much as in 2011.

\section{Regions in Central Mexico}

Michoacán is the hub of strawberry production in Central Mexico, with $79 \%$ of the planted area in 2014. Michoacán has a favorable geographical location and mild, temperate climate for strawberries. Prior to the 1950s, strawberry production in Central Mexico was concentrated in the state of Guanajuato. After production expanded to the state of Michoacán, Michoacán has seen a sharp increase in production and has become a leading producer, while production in Guanajuato has been steadily decreasing. In 1999, 6,140 and 9,090 acres were planted in Guanajuato and Michoacán, respectively. In 2014, their acreages changed to 2,196 and 14,569 acres, respectively (Figure 2). The valley of Zamora is the strawberry center of Michoacán in terms of acreage, output, workforce, and number of agro-processing companies. Strawberries are also grown in the adjacent states, including Jalisco and Mexico states, but the total acreage is quite small there.

\section{Strawberry Technology}

It is technology that has made Michoacán stand out as one of the largest strawberry-producing regions in North America. One of the critical revolutionary technologies is the use of high tunnels, which accounts for about 90\% of the acreage in Central Mexico. High tunnels are

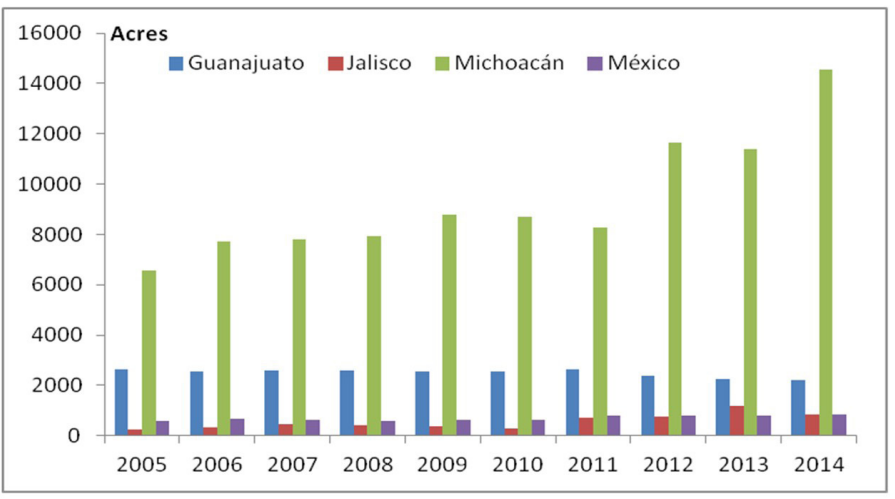

Figure 2. Strawberry planted acreages in four states of Central Mexico, 2005-2014 (Source: Agrifood and Fisheries Information Service of Mexico 2016).

polyethylene-covered, unheated aluminum structures. The frames of high tunnels consist of aluminum pipes bent into an arc roof as well as vertical pipes jointed with the arc on one end and affixed to the ground on the other end. Generally, arcs that make up the tunnel stand 4 meters apart; each arc spans 6 meters, covering 6 beds. The impermeable polyethylene film can be removed after the strawberry season. The film and frame last up to three to five years, respectively.

Before the introduction of high tunnels, the strawberry crop in this region suffered from freeze events, heavy rains, and intense heat. High tunnels provide protection from unfavorable weather conditions and ensure a better survival rate of strawberry transplants. They also extend the production season to increase crop yield. More importantly, strawberries grown under tunnels meet the quality requirements for export to the United States, which has attracted US shippers, particularly California shippers, to invest or engage in Central Mexico's strawberry production. California produces a low volume of strawberries during the winter. Central Mexico is an ideal area for them to produce winter strawberries to meet consumer demand year-round.

High tunnel production requires a significant capital investment. Constructing one hectare of high tunnels costs between 235,000 and 250,000 pesos ( $\$ 7,600-\$ 8,100 /$ acre). Growers' demand for substantial upfront capital investment usually cannot be met by the Mexican domestic banking system. By means of contracting with Mexican growers, US shippers (buyers) provide financial support in exchange for strawberry contracts from growers. This model is popular in Central Mexico and has played a key role in driving production expansion in Mexico. As a result, other technologies used in the United States, such as drip irrigation and the use of certain chemicals, have been also introduced in Mexico. Recently, investment has been aimed at the 
development of new varieties and food safety. As a result, Mexican strawberry production is adopting more and more US technology and management practices.

\section{Strawberry Varieties}

The strawberry industry in Central Mexico has benefited from planting varieties from California and Florida. The Festival variety, which was released by the University of Florida in 2000, is estimated to account for the greatest share of planted acreage. The popularity of this variety is due to its high yield, long shelf-life, and firmer fruits that can be shipped longer distances. Another variety developed by the University of Florida, Florida Radiance, is not common in Central Mexico because this variety is made available to only a few growers to limit competition. California varieties are also popular, including Monterey, Camino Real, Albion, San Andreas, and Sweet Ana. Among these varieties, Monterey is the favorite. Camino Real, which produces high late-season yields of flavorful fruit, is favored by farmers who keep plants for two seasons. In addition to the varieties listed above, private companies plant their own varieties in Central Mexico. Driscoll, Inc., which is dedicated to breeding plants resistant to diseases and pests while meeting quality standards for flavor and appearance, has developed patented varieties in Central Mexico.

Most growers buy transplants from local nurseries. Some of the large-scale growers have their own nurseries and produce strawberry plants for themselves and other commercial growers. Large-scale growers often select highelevation sites and cover nursery fields with screens (Figure 3). They buy mother plants from California nurseries and propagate daughter plants in their own fields. These nursery fields are planted in December and harvested in July of the next year. The average propagation rate for the Festival strawberry is about 60 daughter plants per mother plant, with the quality of daughter plants varying significantly. To compensate for royalties charged for mother plants, sometimes smaller daughter plants are packed for sale by nurseries. Or nurseries may propagate fewer plants and select only good-quality plants; this type of propagation averages about 35 daughters per mother plant. Although these plants are more expensive, they increase transplant vigor, productivity, and fruit quality.

\section{Cultural Practices}

Like Florida and California strawberries, strawberries in Central Mexico are planted in double rows on soil that is mounded into raised beds. Raised beds have good internal soil drainage to provide roots sufficient oxygen for survival during periods of heavy rains (Chandler et

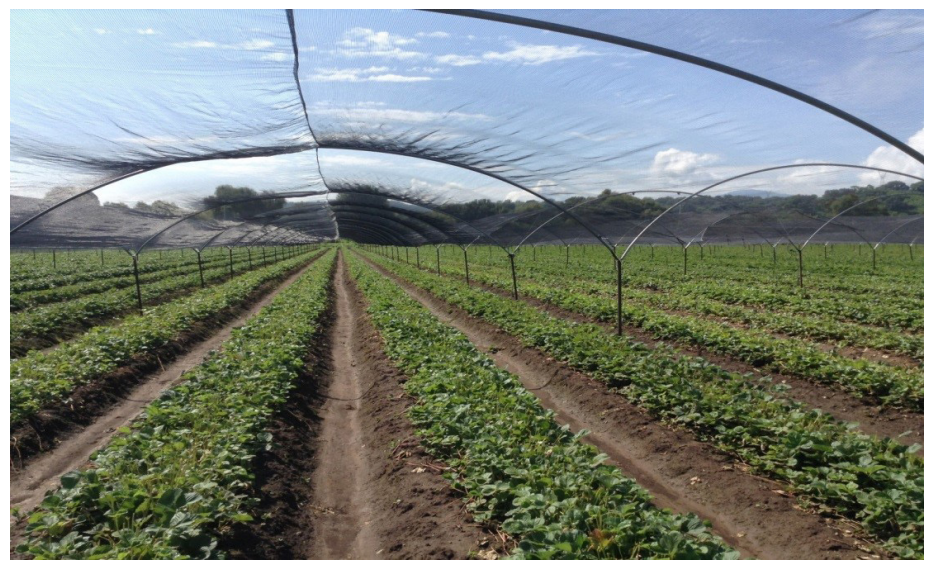

Figure 3. A nursery covered by screen in Central Mexico. Credits: Feng Wu, UF/IFAS

al. 2008). Rows on each bed are spaced 9.84 inches ( 25 $\mathrm{cm})$ apart, whereas in-row spacing is 7.87 inches $(20 \mathrm{~cm})$ apart. Both are narrower than those in Florida (Table 1). As a result, common transplant population is 32,400 per acre (80,000 per hectare) in Central Mexico, compared to 18,000 transplants per acre in Florida. But some growers in this area use a less dense system with 24,300 transplants per acre (60,000 per hectare). High plant density results in a higher yield. Similar to Florida, Central Mexico also uses a bed plasticulture system with drip irrigation. While black mulch is used in Florida, Central Mexico mainly uses white mulch as a full-bed cover. Transplants are commonly set during July and August in Central Mexico. Plants will bear fruit from November to June, a longer fruiting season than Florida. Plants that are set earlier can start to produce fruit in October.

Strawberries are grown as an annual crop in the United States. The plants are removed after the first harvest season and new transplants are established in the subsequent season. However, plants are often kept to bear crops for two years in Central Mexico (a common practice when using high tunnels). The crop in the second year produces fewer (earlier) fruit, but growers can save on land preparation and transplant costs to avoid costly re-installments of high tunnels.

There are two major practices necessary to keep plants for two seasons. One is to water and fertilize plants in a normal way while controlling runners during the transition from one season to the next. The other is to prune plants immediately following harvest. The prune/cleanup method used is to mow the strawberry plants down to a 2 -inch to 4 -inch height, but not cut the crowns, and then clear leaves out of 
the beds and drainage (Figure 4). Pruning is to rejuvenate the plants and maintain their productivity, while cleanup helps reduce disease pressure. Strawberries in the open field are generally grown on an annual basis because plants do not grow well in the rainy season of April and May.

\section{Yield, Harvesting, and Marketing}

In Central Mexico, harvest begins in October and continues until June, with the peak harvest occurring from January to March. Michoacán's strawberries reach the market first with high prices, whereas Guanajuato starts the season late

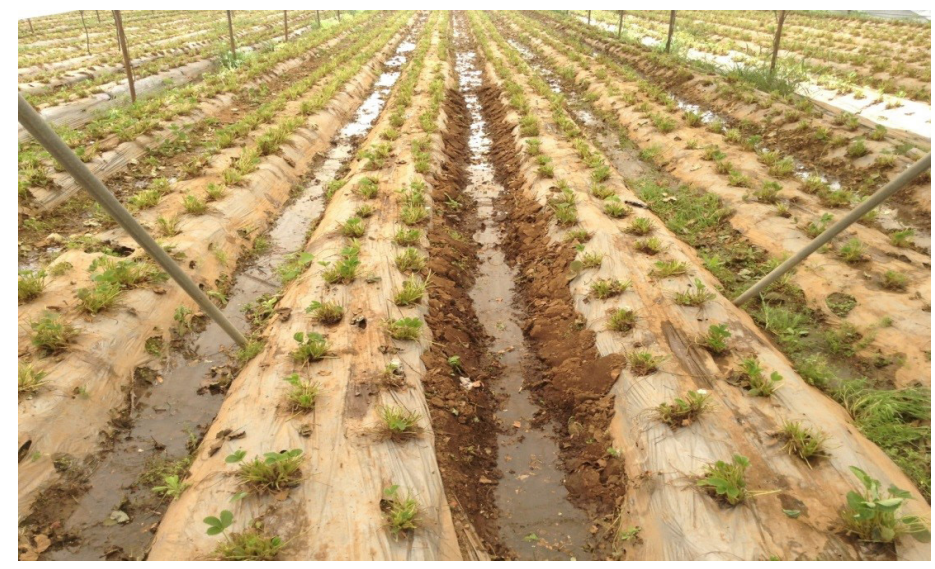

Figure 4. Strawberry rejuvenation pruning in Central Mexico. Credits: Feng Wu, UF/IFAS

and receives a relatively low price. There are three market destinations for strawberries under high tunnels in Central Mexico: fresh export market, fresh domestic market, and domestic processing market. Strawberries in open fields are only supplied to domestic markets because their quality is often not up to the export standard.

Production under high tunnels has higher yields. The yield of the first-year plants is usually around 6,675 flats per acre $(60,000 \mathrm{~kg} / \mathrm{ha})$, and that of the second year plants is about 4,675 flats per acre $(42,000 \mathrm{~kg} / \mathrm{ha})$, with $70 \%$ of the yield being first-year plants. Under high tunnels, about $30 \%$ of the acreage is second-year plants. Approximately $25-30 \%$ of strawberries under tunnels are supplied to the fresh export market, about $60 \%$ of the harvest is sold for processing, and the remaining harvest is sold to the domestic fresh market. Early-season fruit has good quality, and is mainly exported. The export market is from November to March; sometimes it extends to April but it could terminate sooner in February, depending on US import demand and the fruit quality. Exported strawberries receive the highest price, followed by fresh domestic strawberries and strawberries for processing. In the 2013/14 season, growers received prices of 25-28.5 pesos/kg, 9 pesos $/ \mathrm{kg}$, 8.5 pesos $/ \mathrm{kg}$ for fresh export, fresh domestic, and processing strawberries, respectively. The large price differential has motivated growers to produce more and more strawberries under high tunnels for the export market.

\section{Concluding Remarks}

Mexican strawberry production capacity has increased rapidly since 2004. Central Mexico has been the main source of growth; acreage in Central Mexico increased by approximately 50\% between 2011 and 2014. A combination of government subsidies under the Mexican Strategic Project for Protected Agriculture launched in 2009 (Diario Oficial 2010; Victoria et al. 2011) and foreign direct investments (FDI) from the United States may have been the main driving force. High-tunnel technology, which has been widely adopted in Central Mexico, has increased yield significantly. The Agrifood and Fisheries Information Service of Mexico (2016) reported that the average Central Mexican strawberry yield was approximately 5,000 flats per acre between 2013 and 2015 (includes both high-tunnel and open-field crops), which is significantly higher than that of Florida (3,000 flats).

Mexican strawberry production has a major advantage in labor cost and labor supply. The same advantage has also boosted the growth in other commodities such as tomatoes and peppers (Wu et al. 2017). As a labor-intensive operation, strawberry production in Mexico has great potential. Despite rapid growth, Mexican strawberry exports are almost exclusively destined for the US market, which poses a risk to both Mexican and American growers. Oversupply in the US market will cause damage to both the Mexican and the US strawberry industries. Developing the Mexican domestic market and diversifying export destinations will make the industry more sustainable.

\section{References}

Agrifood and Fisheries Information Service of Mexico. 2016. Statistical Yearbook of Agricultural Production.http:// www.gob.mx/siap /.

Chandler, C.K., N.A. Peres, V.M. Whitaker, H.A. Smith, and S.P. Brown. 2008. Growing Strawberries in the Florida Home Garden. HS1154. Gainesville, FL: University of Florida Institute of Food and Agricultural Sciences. http://edis.ifas. ufl.edu/hs403.

Diario Oficial, Quinta Sección, Secretaria de Agricultura, Ganadería, Desarrollo Rural, Pesca y Alimentacion (SAGARPA), 31 de Diciembre de 2010. 
FAO. 2014. FAOSTAT Database. Rome, Italy: Food and Agriculture Organization of the United Nations. http:// faostat3.fao.org.

Suh, D.H., Z. Guan, and H. Khachatryan. 2017. "The impact of Mexican competition on the U.S. strawberry industry." International Food and Agribusiness Management Review. Forthcoming.

United States Census Bureau. 2015. World Trade Atlas. Washington, DC: U.S. Census Bureau.

Victoria, N.G., O. van der Valk, and A. Elings. 2011. Mexican Protected Horticulture: Production and Market of Mexican Protected Horticulture Described and Analysed. Report GTB-1126. Wageningen UR (Wageningen, The Netherlands) and Dutch Agricultural Economic Research Institute (The Hague).

Wu, F., Z. Guan, and D.H. Suh. 2017. "The effects of tomato suspension agreements on market price dynamics and farm revenue." Applied Economic Perspectives and Policy. Forthcoming.

Table 1. Strawberry planting configuration (2-row beds)

\begin{tabular}{|lcc|}
\hline & Florida & Central Mexico \\
\hline Distance between rows (inches) & $12-14$ & $9.84(25 \mathrm{~cm})$ \\
Distance between plants (inches) & $12-16$ & $7.87(20 \mathrm{~cm})$ \\
Plant population (plants/acre) & $16,000-22,000$ & $32,400(80,000 \mathrm{plants} / \mathrm{ha})$ \\
\hline
\end{tabular}

